\title{
Scales of Inequality: Nation, Region, Empire
}

\author{
Alessandro Stanziani
}

If inequality has returned to the center of economic, intellectual, and political debate, it is thanks to Thomas Piketty, whose research over the last fifteen years has integrated historical dynamics, economic analysis, and public policy-a rare feat, especially at such a level of intellectual sophistication. Since the beginning of the twenty-first century, numerous studies produced by both academic institutions and international organizations have highlighted the return of inequality and its impact on social balance and economic growth. The advantage of Piketty's work, however, is that it incorporates a strong historical dimension as well as an impressive mass of data relating not only to numerous Western countries but also to non-Western countries such as India. ${ }^{1}$ It is precisely the spatial and temporal scales of his analysis that will be discussed here, beginning with the question of a Western "specificity" (if indeed such a thing exists) in terms of growth and inequality. To what extent is the relation between these variables, as outlined by Piketty, valid for non-European worlds such as Asia and Africa?

This leads to the question of the pertinent scales of comparison. Piketty produces comparisons between nations, but is the nation the relevant unit for studying

This article was translated from the French by Arby Gharibian and edited by Chloe Morgan, Stephen Sawyer, and Nicolas Barreyre.

1. See the work of Pranab Bardhan, who has collaborated with Piketty, particularly Awakening Giants, Feet of Clay: Assessing the Economic Rise of India and China (Princeton: Princeton University Press, 2010). Bardhan has also written a review of Piketty's work in Economic and Political Weekly 49, no. 25 (2014): http://www.epw.in/book-reviews/ capitalist-dynamics-and-plutocrats.html. 
inequality? How can regional and infranational differences be taken into account alongside imperial, international, and global ones? The first part of this article will discuss national, regional, and trans-regional scales, particularly in terms of the comparative analysis of the historical development of economies. This same question of scales will then be considered with regard to taxation and public policy, by highlighting the role of empire in relation to that of the nation and, potentially, to that of cities.

\section{Comparative Growth Rates}

Despite the differences in size that Piketty emphasizes-for example between France and the United States-it is necessary to ask whether the "Western" economy has really shown significant specificities in terms of growth, taxation, and inequality in comparison to other types of economic arrangements. And, if these specificities exist, can they be explained by differences in institutions, "mentalities," and cultures, or simply by unequal access to resources and consequently by the operation of supply and demand?

Some economic historians, such as David Landes, Eric Jones, and Gregory Clark, locate the origin of different economies in "culture," arguing that they are otherwise identical from the perspective of institutions and the laws of supply and demand. ${ }^{2}$ According to this theory, Britain's achievements, like Africa or Asia's "backwardness," are the result of their respective "cultures": English "bourgeois" culture fostered a spirit of initiative, accumulation, and saving, along with a sense of collective responsibility, innovation, and acceptance of impartial public institutions. Piketty makes no reference to these culturalist arguments, other than to criticize them in the opening chapters of his work. The similarities and differences between Western and non-Western economies must be sought elsewhere. In a less approximative fashion, numerous researchers have recently taken an increased interest in the connections between socioeconomic dynamics and institutions. This process occurred in two phases: some contested the absence of growth in Asia, especially in pre-nineteenth-century China ${ }^{3}$; others subsequently offered explanations of the gap between Europe and the rest of the world using variables other than "culture" and mentalities. Until the early nineteenth century, for instance, some regions of China recorded the same growth rate as Britain or France. The Great Divergence between Europe and Asia was therefore, it was argued, less a product of local institutions (absence of European-style property or representative

2. David S. Landes, The Wealth and Poverty of Nations: Why Some Are So Rich and Some So Poor (New York: W. W. Norton, 1998); Eric Jones, The European Miracle: Environments, Economies, and Geopolitics in the History of Europe and Asia (Cambridge: Cambridge University Press, 1981; repr. 2003); Gregory Clark, A Farewell to Alms: A Brief Economic History of the World (Princeton: Princeton University Press, 2007). Press, 1998). 
institutions, etc.) than of European colonialism, and especially access to metals, raw materials, and American markets. ${ }^{4}$ Europe's strength thus lay in the access that it gained to American, African, and Asian resources and markets. Conversely, the ground that China and Asia lost, generally during the nineteenth century, was attributed to the absence of expansionist policies resembling those of Europeans rather than to the institutions of these countries.

However, authors such as Patrick O’Brien, Angus Maddison, Stephen Broadberry, and Bishnupriya Gupta-whose work is discussed by Piketty-have contested revisionists like Kenneth Pomeranz, demonstrating that a significant disparity between European and Asian growth existed as early as the sixteenth century and that, in this context, colonies would have carried less importance. ${ }^{5}$ These differences can be explained by the accumulation and diffusion of innovations from the twelfth century on, by the role of commerce and towns, and finally by English institutional reforms, which can be contrasted with the bureaucratic weight of China's predatory state. As with Piketty's work on inequality, these debates brought data and their measurement to the forefront of the discussion. In defense of Pomeranz, Robert Allen and especially Prasannan Parthasarathi have emphasized that critics of the Great Divergence rely on Maddison's estimates, ${ }^{6}$ which were produced by extrapolating data from the 1990s into the past. As these authors have shown for China and certain regions of India, the results would be profoundly different if the reference values were taken from the mid-nineteenth century. In this case, the gap between Europe and the main regions of Asia would be smaller, confirming Pomeranz's argument. ${ }^{7}$

Finally, Daron Acemoglu, Simon Johnson, and James Robinson offer figures and approaches that fall between the two schools. For these authors, Europe's growth rate was higher than that of Asia, even if their estimation of the difference lies halfway between those proposed by Maddison and Broadberry and those of Pomeranz and Allen. ${ }^{8}$ They attribute this disparity partly to institutional differences,

4. Robert Allen et al., "Wages, Prices, and Living Standards in China, 1738-1825: In Comparison with Europe, Japan, and India," Economic History Review 64, no. 1 (2011): 8-38; Kenneth Pomeranz, The Great Divergence: China, Europe, and the Making of the Modern World Economy (Princeton: Princeton University Press, 2000).

5. Stephen Broadberry and Bishnupriya Gupta, “The Early Modern Great Divergence: Wages, Prices and Economic Development in Europe and Asia, 1500-1800," Economic History Review 59, no. 1 (2006): 2-31; Patrick O'Brien, "Ten Years of Debate on the Origins of the Great Divergence," review of The Great Divergence, by Pomeranz, Reviews in History (2010): http://www.history.ac.uk/reviews/review/1008.

6. Angus Maddison, The World Economy: A Millennial Perspective (Paris: Development Centre of the Organisation for Economic Co-operation and Development, 2001).

7. Robert Allen, The British Industrial Revolution in Global Perspective (Cambridge: Cambridge University Press, 2009); Prasannan Parthasarathi, Why Europe Grew Rich and Asia Did Not: Global Economic Divergence, 1600-1850 (Cambridge: Cambridge University Press, 2011).

8. Daron Acemoglu, Simon Johnson, and James Robinson, "Reversal of Fortune: Geography and Institutions in the Making of the Modern World Income Distribution," Quarterly Journal of Economics 117, no. 4 (2002): 1231-94. 
and partly to European colonial expansion, two factors that they consider linked. As Acemoglu and others have shown, ${ }^{9}$ the development of transatlantic commerce fostered the rise of English merchant institutions and encouraged the imposition of political limitations on the Crown and the landed aristocracy.

Piketty only briefly mentions these elements, though he leans in favor of arguments that are critical of the Great Divergence. In reality, a deeper dialogue between his work and the debate on the Great Divergence would be beneficial to all involved. Any analysis of inequality in Europe would be enriched by comparison with India, China, or Russia, for example; in return, global historians, who often concentrate on "culture" and institutions, would gain a great deal from an analysis of the relations between economic dynamics and inequality. In what follows, I will evoke a few possible examples of interaction between these two approaches.

\section{Fiscal Systems and Economic Dynamics: Multiple Scales}

The national dimension dominates Piketty's analysis, which provides data comparing France, Great Britain, the United States, India, and so on. This corresponds perfectly to the organization of fiscal data, but also to the majority of analyses conducted to date by both economists and international organizations. As Piketty reminds us at the beginning of his work, national accounts constitute both the source and the main reference for his analyses. Nevertheless, the question of whether the nation is the relevant unit for discussing inequality must be posed.

At first glance, the response is positive for a number of reasons: the production of available data reflects administrative and economic reality; taxation takes place on the scale of the nation, as does public spending (education, health, etc.); studies by international organizations are most often conducted on a national basis; and political-economic solutions also take shape on this scale. The organization of economic indicators according to nation thus encourages the use of this dimension for comparisons-an easy solution, but not without its own disadvantages. In fact, taxation itself was rooted in local institutions such as municipalities or regions for a very long time before it acquired a national dimension and, more recently, a plural one (regional, municipal, national, and international). ${ }^{10}$ It is not by chance that historians of both the eighteenth and nineteenth centuries increasingly draw on local archives, including fiscal archives, as a starting point for highlighting the immense disparity between cities and regions, not just in terms of revenue but also in terms of economic dynamics. ${ }^{11}$

9. Acemoglu, Johnson, and Robinson, "The Rise of Europe: Atlantic Trade, Institutional Change and Economic Growth," American Economic Review 95, no. 3 (2005): 546-79. 10. Bartolomé Yun-Casalilla and Patrick O'Brien, eds., The Rise of Fiscal States: A Global History, 1500-1914 (Cambridge: Cambridge University Press, 2012).

11. Gilles Postel-Vinay, "The Dis-Integration of Traditional Labor Markets in France: From Agriculture and Industry to Agriculture or Industry," in Labor Market Evolution: The Economic History of Market Integration, Wage Flexibility and the Employment Relation, 
Nevertheless, it must be asked whether these infra- and supranational dimensions were widespread, or whether they gave way to fiscal centralization from the eighteenth century on, with other countries gradually following Britain's example. One of the most common arguments in economic history involves demonstrating the English exception in matters of fiscal centralization. According to this view, European-and especially British-reforms supported the Industrial Revolution, while Chinese institutional resistance limited the economic growth of that country. This approach has recently been emphatically renewed by O'Brien and other researchers, who have advanced a global approach to the emergence of the fiscal state, demonstrating the essential differences between English fiscal centralization and the tardiness of other parts of Europe and especially Asia. ${ }^{12}$ In fact, the English fiscal revolution deserves a more nuanced approach in terms of both its scope and its chronology. There is no doubt that Britain was the first country to forcefully limit arbitrary taxation and to impose controls on the Crown through representative institutions. Nevertheless, this process clashed with two other types of institution, and as a result with two other scales: the East India Company (EIC) on the one hand, and regional and local institutions on the other. The centralizing ambitions of Parliament and the central authorities had to take into account the role of parishes and counties in tax collection and public spending. ${ }^{13}$ Administration of the Poor Laws was handled on a local level, as was the implementation of the first school and public health systems. ${ }^{14}$ This often chaotic administration was criticized on numerous occasions, but a genuine solution was not found until the twentieth century, in particular its latter half.

This regional dimension of taxation added another layer to the complexity of imperial administration. From the seventeenth to the mid-nineteenth century, the EIC was a unique kind of institution. Historians interested in its more strictly economic aspects have highlighted its monopoly and, more rarely, the innovative nature of its financial models, which in a way anticipated modern joint-stock companies. ${ }^{15}$ As a result, they have not shied away from comparing the EIC to a "corporate body" similar to the guilds. ${ }^{16}$ On the other hand, historians of English taxation, the British Empire, or the British military conquest of India have asserted that the EIC was more than a form of guild, and that it well and truly represented

ed. George Grantham and Mary MacKinnon (London/New York: Routledge, 1994), 64-83; Robert Allen, Enclosure and the Yeoman (Oxford: Oxford University Press, 1992); Nick F. R. Crafts, "Regional Price Variations in England in 1843: An Aspect of the Standardof-Living Debate," Explorations in Economic History 19 (1982): 51-70.

12. Yun-Casalilla and O'Brien, Rise of the Fiscal State.

13. O'Brien, "Ten Years of Debate."

14. Peter Lindert, Growing Public: Social Spending and Economic Growth since the Eighteenth Century (Cambridge: Cambridge University Press, 2004).

15. Ron Harris, "Law, Finance, and the First Corporations," in Global Perspectives on the Rule of Law, ed. James J. Heckman, Robert L. Nelson, and Lee Cabatingan (Abingdon: Routledge, 2010), 145-72.

16. Philippe J. Stern, The Company-State: Corporate Sovereignty and the Early Modern Foundations of the British Empire in India (New York: Oxford University Press, 2011). 
a state within the British state, with its own army, budget, and tax revenues. ${ }^{17}$ The numerous wars that led to the occupation of a large part of the Indian subcontinent, from the Battle of Plassey (1757) to the Sepoy Rebellion (1858), were conducted first and foremost by EIC soldiers. ${ }^{18}$ The EIC also had the right to levy taxes in areas under British control, and its issuance of securities and its commerce heavily influenced monetary circulation in the Indian Ocean and Europe. These were the essential functions of states during the early modern period, and it is no coincidence that voices rose up in Parliament on numerous occasions to protest against the EIC's sovereignty. ${ }^{19}$ The situation evolved only with the end of the EIC's privileges between 1857 and 1863, followed by tax reforms between 1880 and 1914 . Considering that this was long after the Industrial Revolution, it is difficult to explain the latter through British fiscal centralization.

To put it another way, fiscal centralization was above all the ambition and political goal of a part of the English elite, but it became a reality only after the Industrial Revolution. Associating taxation outside of Europe simply with predatory or despotic regimes is just as problematic as explaining the dynamics of eighteenthand nineteenth-century England through the "fiscal revolution." For instance, Pomeranz has criticized the traditionally negative image of China's fiscal administration as fragmented and corrupt by demonstrating its effectiveness. Bin Wong initially adopted a nuanced position closer to Pomeranz's, though in his later collaboration with Jean-Laurent Rosenthal he emphasized the limits of Chinese fiscal administration, especially in comparison to that of Britain. ${ }^{20}$

The implications of these debates for Piketty's analyses are obvious: it was not nation but rather region, county, municipality, and empire that played a central role in the relation between taxation, inequality, and economic growth. This growth was not necessarily halted by the presence of rentiers (a concept we must be very careful to qualify-in China, in Belle-Époque France, during our own time, etc.), nor by the absence of representative institutions (a classic argument linking England's success to its "glorious revolution"). The absence of a genuinely democratic political regime in no way prevented growth, as demonstrated by the examples of Europe before the First World War (where voting rights were limited to a few landowners

17. On these aspects see Kaushik Roy, "Military Synthesis in South Asia: Armies, Warfare, and Indian Society, c. 1740-1849," Journal of Military History 69, no. 3 (2005): 651-90; Alessandro Stanziani, Bâtisseurs d'empire. Russie, Inde, Chine à la croisée des mondes, $X V^{e}$-XIX $X^{e}$ siècle (Paris: Raisons d'agir, 2012).

18. Raymond Callahan, The East India Company and Army Reform, 1793-1798 (Cambridge: Harvard University Press, 1972); Seema Alavi, The Sepoys and the Company: Tradition and Transition in Northern India, 1770-1830 (Delhi: Oxford University Press, 1995).

19. Anthony Farrington, Trading Places: The East India Company and Asia, 1600-1834 (London: British Library, 2002); John Richards, "Fiscal States in Mughal and British India," in Yun-Casalilla and O'Brien, The Rise of the Fiscal State, 410-41.

20. Bin Wong, China Transformed: Historical Change and the Limits of European Experience (Ithaca: Cornell University Press, 1997); Jean-Laurent Rosenthal and Bin Wong, Before and Beyond Divergence: The Politics of Economic Change in China and Europe (Cambridge: Harvard University Press, 2011). 
during the nineteenth century, then gradually widened), Russia during the second half of the nineteenth century and again today, and notably China throughout almost its entire history. These historical examples also demonstrate that a high growth rate is insufficient to reduce inequality (as in the European pattern described by Piketty), especially if particularly coercive and inegalitarian institutions intervene. Nor, finally, is it true that such institutions spontaneously disappear with the rise of markets and economic growth. ${ }^{21}$ Must we then conclude, as do Allen, Wong, and Rosenthal (among others) that the differences between the West and Asia depended less on economic institutions than on geopolitical dynamics on the one hand and the availability of resources and forms of demand on the other?

\section{Growth, Regional Poles, and Empires}

Contrary to the conventional analyses emphasizing the nation-state, ${ }^{22}$ recent studies have highlighted the importance of empires over the very long term, well beyond the presumed point of transition from empire to nation-state. During the seventeenth century, in Europe as in Asia, national constructions relating to administration, politics, and identity were realized at the same time as empires were being built. ${ }^{23}$ Over the last decade, there has been a spectacular rise in studies devoted to these imperial dynamics. Yet one important aspect remains somewhat sidelined in these new approaches, namely the question of the relations between imperial dynamics, growth, and inequality. In underscoring that, in contrast to China, Europe's-and especially Britain's — strength lay in empire, Pomeranz neglects the fact that China itself was an imperial construction, within which hierarchies and even tensions between the various Mongolian and Han populations and elites played a constant role. Contrary to these arguments, therefore, it was not empire itself that distinguished Britain from China, but its organization and its impact on growth and inequality. This is where Piketty's approach becomes essential: we would gain much by linking his analysis of inequality in the major Western countries to imperial constructions. Is it possible to measure the impact of imperial construction during the Qing Dynasty on social and economic dynamics? And how should this process be distinguished from that which drove Western powers during the same period?

In the case of European empires, the classic debate has focused on whether colonialism was profitable for the West. For Marxist authors from Eric Williams to

21. Acemoglu, Johnson, and Robinson, "Reversal of Fortune"; Alessandro Stanziani, After Oriental Despotism: Eurasian Growth in a Global Perspective (London: Bloomsbury, 2014).

22. Charles Tilly, Coercion, Capital and European States, AD 990-1990 (Oxford: Blackwell, 1990).

23. The best expression of this tendency is surely Jane Burbank and Frederick Cooper,

Empires In World History: Power and the Politics of Difference (Princeton: Princeton University Press, 2010). 
Immanuel Wallerstein, the answer was positive. ${ }^{24}$ This was subsequently criticized at length, ${ }^{25}$ but it has recently been revived in the work of Acemoglu, ${ }^{26}$ which is strongly inspired by the estimates of Joseph Inikori. ${ }^{27}$ Inikori did not limit his analysis to the profits directly associated with the Atlantic slave trade, but added the impact of the triangular trade between Europe, America, and Africa onto England's overall commercial growth, then onto the profitability of the textile industry (technological evolution, imports, sales), while also taking into account the transformations of English institutions. In particular, Inikori and subsequently Acemoglu have shown that transatlantic trade encouraged the adoption of regulations that were more favorable to commerce and manufacture as well as more protective of private property and income. All of these elements contributed to increasing Britain's rate of profit. ${ }^{28}$ Yet none of these authors thought to link these analyses to studies on inequality in Britain itself, which in turn remain confined to classic debates on the level of wages in relation to growth, technological progress, and customs policy. In these studies, it is as though the empire did not exist. Since we now have new and detailed information on both colonial profits and the evolution of salaries and profits in Britain, however, it is time to connect the two. ${ }^{29}$

This omission is even more pronounced for France, for although the bibliography on the political, social, and cultural history of French colonial empires is considerable, detailed assessments of the economic role of these empires remain fragmentary. Case studies are numerous but difficult to connect to one another, while broader studies often lack data and limit themselves to retreading the conventional debate, with some minimizing the importance of colonial profits ${ }^{30}$ and others emphasizing their highly negative impact on the colonies. ${ }^{31}$ However,

24. Eric Williams, Capitalism and Slavery (Chapel Hill: Northern Illinois University Press, 1944); Immanuel Wallerstein, The Capitalist World-Economy (Cambridge: Cambridge University Press, 1979).

25. Rondo Cameron, A Concise Economic History of the World: From Paleolithic Times to the Present (Oxford: Oxford University Press, 1989); Frederick Cooper, Colonialism in Question: Theory, Knowledge, History (Berkeley/Los Angeles: University of California Press, 2005).

26. Acemoglu, Johnson, and Robinson, "The Rise of Europe."

27. Joseph E. Inikori, Africans and the Industrial Revolution in England: A Study in International Trade and Development (Cambridge: Cambridge University Press, 2002).

28. On this subject see also Ronald Findlay and Kevin H. O'Rourke, Power and Plenty: Trade, War, and the World Economy in the Second Millennium (Princeton: Princeton University Press, 2007).

29. Some efforts in this direction have nevertheless been made in a comparison between the Dutch and British empires with regard to sugar production: Ulbe Bosma, The Sugar Plantation in India and Indonesia: Industrial Production, 1770-2010 (Cambridge: Cambridge University Press, 2013).

30. Paul Bairoch, Economics and World History: Myths and Paradoxes (Chicago: University of Chicago Press, 1993); Jacques Marseille, Empire colonial et capitalisme français. Histoire d'un divorce (Paris: Albin Michel, 1984).

31. Catherine Coquery-Vidrovitch, Le Congo au temps des grandes compagnies concessionments français outre-mer : firmes d'Afrique occidentale," in La position internationale de 
recent research has begun gathering more data with the aim of establishing the links between colonialism, inequality, and economic dynamics. Guillaume Daudin has examined data connecting colonial trade to the economic dynamics of France itself. ${ }^{32}$ Denis Cogneau has likewise begun important research on postcolonial Africa that aims to measure the impact of decolonization in terms of growth, taxation, and inequality. ${ }^{33}$ Nevertheless, much work remains to be done, especially for the colonial period itself where data is more fragmentary.

In an ideal world, these subtle analyses of colonial dynamics would intersect with Piketty's data on the evolution of inequality in metropolitan France. For example, what link can be established between the dynamics of wealth that he describes for the nineteenth century and French colonial expansion? As Piketty reminds us, the end of the nineteenth century and the Belle Époque were characterized by a growing divergence between $r$ and $g$, and consequently by the increasing influence of rentiers. Foreign investments (in Russia, in the Ottoman Empire) are often evoked to account for the rise of rentiers during this period. But was this the only factor?

In essence, these dynamics emerged at the same moment that France embarked on its colonial adventure in sub-Saharan Africa, which entailed costs and also provided resources of which the effective nature and composition have yet to be specified. Statistics relating to customs make it possible to measure the importance of trade between France and its colonies, which represented France's third trading partner in 1900, its second in 1924, and, four years later, had become the first. France imported raw materials, while its colonies provided markets for its manufactured goods. At the same time, colonial companies represented 25 percent of stock issued outside metropolitan France in 1913, and 70 percent fifteen years later. ${ }^{34}$ In terms of costs, contributions from public funds represented a significant proportion of spending and investment in the colonies, primarily in the form of infrastructure. Although this spending was high in percentage terms, it remained limited, especially before 1914-it would increase after the First World War. ${ }^{35}$ Élise Huillery has recently provided more precise information for this debate by distinguishing subsidies from loans and making extensive use of colonial budgets. ${ }^{36}$

la France. Aspects économiques et financiers, XIX ${ }^{e}-X X^{e}$ siècles, ed. Maurice Lévy-Leboyer (Paris: Éd. de l'Ehess, 1973), 413-26; Marc Ferro, ed., Le livre noir du colonialisme, $X V I^{e}-X X I^{e}$ siècle. De l'extermination à la repentance (Paris: R. Laffont, 2003).

32. Guillaume Daudin, "Empires et économie," http://spire.sciencespo.fr/hdl:/2441/ 516uh8ogmqildh09h4dqk0kai/resources/empireseteconomieversionpreliminaire.pdf.

33. Denis Cogneau, L'Afrique des inégalités. Où conduit l'histoire (Paris: Éd. de la rue d'Ulm, 2006).

34. Marseille, Empire colonial, 134.

35. Catherine Coquery-Vidrovitch, "Le financement de la 'mise en valeur coloniale' méthode et premiers résultats," in Études africaines offertes à Henri Brunschwig (Paris: Éd. de l'Ehess, 1982), 237-52.

36. Élise Huillery, "Histoire coloniale, développement et inégalités dans l'ancienne Afrique occidentale française" (PhD diss., EHEss, 2008). 
It is thus time to consider the relation between these dynamics and those identified by Piketty for metropolitan France: What connection can be established between colonization and the evolution of $r, g$, and their interrelation from 1870 to 1914 ? Two contradictory dynamics were simultaneously taking place during the three decades that followed the Second World War, known in France as the Trente Glorieuses, or "Thirty Glorious Years": in Europe, growth rose and inequality shrank, while the collapse of colonial empires had a major economic impact not only on the Global South but also on Europe. These dynamics presented important costs and, potentially, revenues in the mid-term, as former colonizers sought to maintain economic influence over their erstwhile colonies. In terms of prices and taxation, for example, trading conditions changed significantly over the period of decolonization, as implementation of the labor code in the colonies increased the cost of their products even though the French state sought to grant fiscal advantages and measures to support prices. Loans, which had dominated public transfers in French West Africa until that point, gave way to subsidies and, in particular, to advances. ${ }^{37}$

At this stage, it is a question of identifying the links between these flows and inequality, not only in former colonies but also in Europe itself. Numerous studies have attempted to measure the impact of decolonization on developing countries. We are nevertheless lacking analyses that connect the dynamics of inequality in Europe during the Trente Glorieuses to the geopolitical and economic evolution of former colonial empires-with the notable exception of the phenomenon of immigration and, in part, that of capital export. What connections can be established between these dynamics? In particular, is there a link between the rise of the social state and decolonization?

There is of course the question of the costs and benefits of decolonization, both for European countries and for their former colonies. These have begun to be measured for certain African countries from the former British and French empires. ${ }^{38}$ Much remains to be done, but recent trends offer hope that research on these topics will move beyond purely ideological debate. These elements make it possible to understand transfers between the metropoles and their colonies, and the impact of these transfers on growth. This panorama can then be completed with what we now know, thanks to Piketty, regarding the evolution of the social state and inequality in metropolitan France itself: Did the social state spread as a complement to decolonization or rather in opposition to it? In other words, did decolonization make it possible to enlarge the social state to former colonies? Or, if not, did it also work to drastically limit the access that inhabitants of these former colonies had to the social state in the metropole?

37. Huillery, "The Black Man's Burden: The Cost of Colonization of French West Africa," Journal of Economic History 74, no. 1 (2014): 1-38.

38. Cogneau, L'Afrique des inégalités; Huillery, "Histoire coloniale"; Kevin Sylwester, "Decolonization and Economic Growth: The Case of Africa," Journal of Economic Development 30, no. 2 (2005): 87-102; Daron Acemoglu, Simon Johnson, and James Robinson, "The Colonial Origins of Comparative Development: An Empirical Investigation," American Economic Review 91, no. 5 (2001): 1369-401. 
A more general question thus emerges, involving not only the circulation of products, capital, and labor, but also that of institutions. Like economic liberalism, the social state travels poorly over time and space. The solutions adopted by Britain or France at the end of the Second World War were difficult to maintain as such in Europe. Moreover, from decolonization to the present day, all of their limitations have been revealed in India and in numerous African and Latin American countries. In Africa as in India, attempts to transplant "European style" social states have given rise to resistance on the part of both local elites and workers. ${ }^{39}$

Any answer to these questions pertains to the economic models and other variables mentioned, namely the forms of politics and sovereignty, and consequently the scales of intervention. Piketty first evokes a utopia (global regulation), then a more modest goal (European regulation), and finally an even more limited solution (an agreement between the strong countries in the eurozone). Except that these final propositions risk generating capital flight away from more heavily taxed areas, not to mention their impact on emerging countries. And what of these emerging countries themselves? Must they adopt the same policies as Europe? Piketty suggests that a convergence between the West and Asia should occur in the next few decades, and therefore the possibility of arriving at common policies. In contrast, Esther Duflo emphasizes the hyper-localism of public policies as an alternative to the generalizations of classic development economics. ${ }^{40}$ Local actors make decisions about public health, credit, or employment based on local values and arrangements, although these are subsequently inscribed in global dynamics. Duflo also focuses her analysis on the "poor," by definition absent from the fiscal sources used by Piketty. Ultimately, however, these approaches are less contradictory than complementary, because in certain cases global policies are necessary to frame their local implementation. Whether it is a question of the wealthiest in Europe or the poorest in India, the focus is thus less on the actual sources of growth-which neither Piketty nor Duflo identify-than on the policies to be adopted so that growth benefits the largest number of people.

Alessandro Stanziani

Centre de recherches historiques - EHESS

39. Frederick Cooper, Decolonization and African Society: The Labor Question in French and British Africa (Cambridge: Cambridge University Press, 1996).

40. Abhijit Banerjee and Esther Duflo, Poor Economics: A Radical Rethinking of the Way to Fight Global Poverty (New York: Public Affairs, 2011). 